\title{
Referaten
}

\section{Carrières van Britse basisartsen}

\author{
Goldacre MJ, Davidson JM, Lambert, TW. Career \\ choices at the end of the pre-registration year of doc- \\ tors who qualified in the United Kingdom in 1996. \\ Medical Education 1999;33(12):882-9.
}

Dit artikel beschrijft de carrière-intenties van Britse basisartsen aan het eind van hun preregistratiejaar. Hiertoe werd een enquête gehouden onder alle artsen die in 1996 het basisartsdiploma behaalden. In totaal werden 3809 vragenlijsten verstuurd. De respons bedroeg $76,8 \%$. Uit de enquête blijkt dat slechts $20 \%$ van de basisartsen in eerste instantie voor huisartsgeneeskunde kiest, terwijl dat in 1993 nog $25,8 \%$ was en in 1983 zelfs $46 \%$. Deze tendens is bij de vrouwelijke artsen nog sterker aanwezig dan bij de mannelijke artsen. Vooral heelkunde zit in de lift met een stijging van $16,9 \%$ in 1993 naar $21,4 \%$ in 1996 . Men kiest vooral voor orthopedie, oogheelkunde, KNO en plastische chirurgie. Het percentage vrouwen blijft klein ten opzichte van dat van de mannen. Voor de inwendige specialismen is er slechts een kleine toename van 22,1\% in 1993 naar $24,9 \%$ in 1996 . Hier zijn vooral cardiologie en gastro-enterologie in trek. Daarnaast is 77\% van de respondenten van plan een praktijk op te bouwen in Engeland. Slechts 1\% kiest voor een niet-medische carrière en $9,4 \%$ stelt dat de mogelijkheid bestaat dat ze ooit uit het beroep zullen stappen. Opvallend is de dalende interesse voor huisartsgeneeskunde. Bovendien stelt bijna $10 \%$ van de respondenten dat de mogelijkheid bestaat dat ze het vak ooit zullen verlaten.

De auteurs geven geen verklaringen voor deze trends. Deze trends zijn ook te zien in bijvoorbeeld Vlaanderen alwaar men deze toeschrijft aan de organisatie van de gezondheidszorg, die niet huisartsvriendelijk is. Mijns inziens zijn ook de toenemende technocratisering van de maatschappij en de steeds hogere eisen die aan huisartsen gesteld worden door patiënten en overheid, bepalende factoren. Verder onderzoek is zeker aangewezen in het kader van 'men-women powerplanning'. Een land met meer specialisten dan huisartsen is geen goede zaak. In Vlaanderen zijn we daar bijna aan toe!

J.P.M. Denekens, Antwerpen.

\section{Naar een realistisch onderwijscarrière- perspectief in een medische faculteit}

\author{
Aucott JN, Como J, Aron DC. Teaching awards and \\ departmental longevity: is award-winning teaching \\ the 'kiss of death' in an academic department of \\ medicine? Perspectives in Biology and Medicine \\ 1999;42(2):280-7.
}

Versterking van de plaats van het onderwijs in een medische faculteit door carrièreperspectieven aan te bieden aan mensen die zich in sterkere mate willen toeleggen op onderwijs krijgt regelmatig aandacht in de literatuur en op congressen. De aanleiding hiervoor is tweeledig. Enerzijds is het op veel medische faculteiten moeilijk om clinici/onderzoekers te bewegen tot een substantiële tijdsinvestering in onderwijs. Anderzijds zijn de carrièremogelijkheden voor hen die zich willen toeleggen op onderwijs beperkt. De laatste jaren wordt ook in Nederland op diverse plaatsen ervaring opgedaan met methoden om onderwijsinspanningen zichtbaar te maken en te waarderen, en worden ook pogingen ondernomen om deze inspanningen mee te laten wegen bij personeelswerving en carrièreplanning. ${ }^{1}$ Zodoende wordt gestreefd naar een gelijkwaardige positie voor onderwijs, naast onderzoeks- en patiëntenzorgprestaties.

Momenteel hebben we te maken met een systeem waarin onderwijsprestaties de carrièrevorming zelfs in de weg kunnen staan. Onlangs brachten Aucott et al. dit nog eens onder de aandacht. Zij verrichtten een onderzoek onder stafleden van de afdeling inwendige geneeskunde. Bestudeerd werd de duur van de aanstelling van winnaars van 'Best Teacher Awards' na het winnen van hun eerste prijs. 